\title{
The Use of Learning Video Media To Improve Science Understanding Of The Fifth Grade Students.
}

\author{
Anisah Suastika Yuanti \\ SDN 3 TEMANGGUNG ॥ \\ anisah.sy16@gmail.com
}

\section{Article History}

accepted 01/11/2020

approved 08/11/2020

published 15/11/2020

\begin{abstract}
The purpose of this study is to improve student understanding in science learning of the fifth grade. This research is a classroom action research (PTK) which is carried out in three cycles, each cycle consists of planning, implementation, observation, and reflection stages. The subject of this study is 20 students of the fifth grade of SDN 3 Temanggung II in the academic year 2020/2021. Data collection techniques use observation and tests. Data analysis includes data reduction, data presentation, and drawing conclusions. Research shows that the use of learning video media can improve science understanding of the fifth grade students in the academic year 2020/2021 evidenced by the percentage of learning outcomes completeness and class average score. In the first cycle only reaches $60 \%$ and the class average score is 76,50 , in the second cycle becomes $100 \%$ with the class average score 83,40 and in the third cycle reaches $100 \%$ with the class average score 86,80.
\end{abstract}

Keywords: Learning Video, Science, Elementary school students

\begin{abstract}
Abstrak
Tujuan Penelitian ini adalah untuk meningkatkan pemahaman peserta didik pada pembelajaran IPA kelas V SD. Penelitian ini merupakan Penelitian Tindakan Kelas yang dilaksanakan dalam 3 siklus. Setiap siklus terdiri dari tahapan perencanaan, pelaksanaan, observasi dan refleksi. Subjek penelitian ini adalah peserta didik kelas V SDN 3 Temanggung II Tahun Pelajaran 2020/2021 yang berjumlah 20 peserta didik. Teknik pengumpulan data menggunakan observasi dan tes. Analisis data meliputi reduksi data, penyajian data, dan penarikan kesimpulan. Penelitian menunjukkan bahwa penggunaan media video pembelajaran dapat meningkatkan pemahaman IPA siswa kelas V tahun pelajaran 2020/2021 yang dibuktikan dengan persentase ketuntasan hasil belajar dan rata-rata kelas. Pada siklus I sebesar $60 \%$ dengan rata-rata kelas 76,50 menjadi $100 \%$ dengan rata-rata kelas 83,40 pada siklus II dan $100 \%$ dengan rata-rata kelas 86,80 pada siklus III.
\end{abstract}

Kata kunci: Video Pembelajaran, Science, Siswa sekolah dasar

Social, Humanities, and Education Studies (SHEs): Conference Series https://jurnal.uns.ac.id/shes 


\section{PENDAHULUAN}

Pendidikan merupakan salah satu bentuk perwujudan kebudayaan manusia yang dinamis dan sarat perkembangan. Oleh karena itu, perubahan atau perkembangan pendidikan adalah hal yang memang seharusnya terjadi sejalan dengan kemajuan kehidupan. Perubahan dalam arti perbaikan pendidikan pada semua tingkat. Memasuki abad 21, sistem pendidikan nasional menghadapi tantangan yang kompleks dalam menyiapkan kualitas sumber daya manusia yang mampu bersaing di era global. Upaya yang paling tepat untuk mengatasi hal tersebut adalah pendidikan melalui proses belajar. Belajar menurut merupakan suatu perubahan tingkah laku pada diri individu berkat adanya interaksi antara individu dengan individu dan individu dengan lingkungan.

Ilmu Pengetahuan Alam memiliki banyak cabang ilmu yang sudah menjadi materi dalam kurikulum pendidikan di Indonesia. Salah satu materi IImu Pengetahuan Alam (IPA) di Sekolah Dasar (SD) adalah Gangguan peredaran darah manusia yang menarik untuk dipelajari. Belajar ilmu pengetahuan khususnya IPA perlu adanya media pembelajaran yang dapat membuat proses pembelajaran dapat diterima dengan baik oleh peserta didik. Sehingga perlu adanya media pembelajaran yang aktif sesuai dengan Kurikulum 2013. Media tersebut perlu diidentifikasi dan perlu diketahui apakah media tersebut efektif, dan bagaimana sikap atau presepsi siswa terhadapnya. Media pembelajaran dapat menunjang pembelajaran saintifik pada kurikulum 2013 yang mana implementasi dari kurikulum 2013 secara benar dapat mengatasi permasalahan sumber daya manusia di negara kita melalui bidang pendidikan. Namun, terdapat kesulitan dalam penerapan kurikulum karena keterbatasan pengetahuan dan wawasan guru terkait dengan konsep pembelajaran

SD Negeri 3 Temanggung II merupakan sekolah yang mengaplikasikan ilmu pengetahuan alam dengan menjaga kelestarian lingkungan sekolah. Hal tersebut tentu menjadi daya tarik tersendiri bagi SD Negeri 3 Temanggung II untuk diteliti lebih lanjut mengenai proses pembelajaran IPA. Disamping itu, siswa-siswi SD Negeri 3 Temanggung II memiliki banyak bakat dan potensi yang mampu untuk dikembangkan baik dibidang akademik maupun nonakademik.

Berdasarkan hasil observasi yang dilakukan pada bulan Oktober 2020, masih banyak siswa yang belum sepenuhnya mampu menyerap materi pembelajaran IPA dengan baik. Ada siswa Kelas V SD Negeri 3 Temanggung II yang masing-masing siswa memiliki daya serap yang berbeda-beda. Hanya 8 siswa yang memiliki daya serap yang baik sehingga perlu diteliti mengapa siswa yang lain kurang dalam hasil belajar. Hasil pembelajaran IPA sering kurang memenuhi KKM (Kriteria Ketuntasan Minimal). Adapun KKM mata pelajaran IPA yang ada di SD Negeri 3 Temanggung II adalah 75. Pembelajaran di kelas yang dilakukan oleh guru cenderung menggunakan cara konvensional berupa ceramah yang membuat siswa tidak bisa mendapatkan kesempatan untuk bisa aktif dalam proses pembelajaran. Untuk memudahkan siswa memahami materi pembelajaran dengan baik, maka perlu media dalam proses pembelajaran. Dengan menggunakan media video pembelajaran, peserta didik akan lebih mudah memahami materi dan hasil belajar yang diperoleh dapat meningkat.

Peneliti mengidentifikasi bahwa media pembelajaran yang digunakan menjadi permasalahan utama dalam meningkatkan pemahaman siswa. Media adalah segala sesuatu yang dapat digunakan untuk menyalurkan pesan dari pengirim ke penerima sehingga dapat merangsang pikiran, perasaan, perhatian dan minat serta perhatian peserta didik sedemikian rupa sehingga proses belajar terjadi (Sadiman, 2008:7). Dalam pengertian yang lebih luas media pembelajaran adalah alat, metode, dan teknik yang dipergunakan dalam rangka lebih mengefektifkan komunikasi dan interaksi antara pengajar dan pembelajar dalam proses pembelajaran di kelas (Oemar Hamalik, 1989). 
Tujuan penggunaan media dalam pembelajaran adalah untuk (1) meningkatkan kualitas dan efektivitas pembelajaran, (2) memudahkan guru, (3) memberikan arahan tentang tujuan yang akan dicapai, (4) menyediakan evaluasi mandiri, (5) memberi rangsanang kepada guru untuk kreatif, (6) menyampaikan materi pembelajaran, dan (7) membantu pebelajar yang memiliki kekhususan tertentu. Fungsi media adalah (1) menyampaikan pembelajaran, (2) konstruksi dari lingkungan, dan (3) mengembangkan keterampilan kognitif.

Berdasarkan tujuan dan fungsinya penggunaan media sangat dibutuhkan dalam mendukung proses pembelajaran. Penggunaan media pembelajaran dapat membuat hal yang bersifat abstrak menjadi lebih konkrit dan membuat suasana belajar yang tidak menarik menjadi lebih menyenangkan. Media pembelajaran yang peneliti gunakan untuk memperbaiki pembelajaran adalah menggunakan media video pembelajaran. Video merupakan serangkaian gambar gerak yang disertai suara yang membentuk suatu kesatuan yang dirangkai menjadi alur, dengan pesan-pesan di dalamnya untuk ketercapaian tujuan pembelajaran yang disimpan dengan proses penyimpanan pada media pita atau disk (Arsyad, 2004:36 dalam Rusman dkk 2011:218). Video merupakan media audio visual yang menampilkan gerak (Sadiman, 2008:74). Jadi dapat disimpulkan bahwa video pembelajaran adalah suatu media yang dirancang secara sistematis dengan berpedoman kepada kurikulum yang berlaku dan dalam pengembangannya mengaplikasikan prinsip-prinsip pembelajaran sehingga program tersebut memungkinkan peserta didik mencemarti materi pelajaran secara lebih mudah dan menarik.

Berdasarkan latar belakang tersebut, timbul keinginan peneliti untuk mengetahui apakah media video pembelajaran memungkinkan siswa lebih mudah memahami materi. Apabila cara tersebut telah diterapkan, sejauh mana efektivitasnya, dan bagaimana pemahaman dan hasil belajar siswa terhadap media pembelajaran tersebut. Maka dari itu, peneliti memberi judul penelitian ini "Penggunaan Media Video Pembelajaran Untuk Meningkatkan Pemahaman IPA Materi Gangguan Dan Cara Memelihara Kesehatan Organ Peredaran Darah Manusia melalui Penggunaan Media Video Pembelajaran pada Siswa Kelas V Semester Ganjil SD Negeri 3 Temanggung II Tahun Pelajaran 2020/2021".

\section{METODE}

Penelitian ini merupakan Penelitian Tindakan Kelas (PTK) yang dilaksanakan dalam tiga siklus, setiap siklus terdiri dari tahap perencanaan, pelaksanaan, observasi, dan refleksi. Subjek penelitian ini adalah peserta didik kelas V SDN 3 Temanggung II Tahun Pelajaran 2020/2021 yang berjumlah 20 peserta didik.

Data yang dianalisis berupa data kualitatif yaitu penggunaan media video pembelajaran dan data kuantitatif yaitu hasil belajar tematik peserta didik. Teknik pengumpulan data menggunakan observasi dan tes. Analisis data meliputi reduksi data, penyajian data dan penarikan kesimpulan.

\section{HASIL DAN PEMBAHASAN}

Berdasarkan analisis hasil penelitian yang telah diuraikan maka pembahasan pada penelitian ini sebagai berikut.

\section{Penggunaan Media video Pembelajaran}

Hasil penelitian menunjukkan peningkatan pemahaman siswa melalui penggunaan video pembelajaran yang dilakukan oleh guru. Terilhat pada tabel berikut: 
Tabel 1. Peningkatan Pemahaman Siswa Melalui Penggunaan Video Pembelajaran

\begin{tabular}{llccc}
\hline NO & \multicolumn{1}{c}{ ASPEK } & SIKLUS I & SIKLUS II & SIKLUS III \\
\hline 1. & $\begin{array}{l}\text { Peserta didik dapat dengan } \\
\text { mudah memahami kalimat } \\
\text { yang ditampilkan pada media } \\
\text { video }\end{array}$ & 3 & 3 & 4 \\
\hline 2. & $\begin{array}{l}\text { Guru menampilkan } \\
\text { background gambar } \\
\text { menggunakan media video } \\
\text { yang disenangi peserta didik }\end{array}$ & 4 & 4 & 4 \\
\hline 3. & $\begin{array}{l}\text { Guru menampilkan animasi } \\
\text { menggunakan media video } \\
\text { yang disenangi peserta didik }\end{array}$ & 4 & 4 & 4 \\
\hline 4. & $\begin{array}{l}\text { Konten materi dalam video } \\
\text { berhubungan dengan materi } \\
\text { yang dipelajari peserta didik }\end{array}$ & 4 & 4 & 4 \\
\hline 5. & $\begin{array}{l}\text { Suara dari dalam video dapat } \\
\text { terdengar jelas sehingga } \\
\text { memudahkan peserta didik } \\
\text { memahami materi }\end{array}$ & 3 & 4 & 4 \\
\hline 6. & $\begin{array}{l}\text { Video pembelajaran sudah } \\
\text { berisi tentang materi yang } \\
\text { memancing peserta didik } \\
\text { untuk berpikir kritis }\end{array}$ & 3 & 3 & \\
\hline
\end{tabular}

Dari data observasi yang diperoleh pada tabel di atas bahwa aktivitas mengajar atau kegiatan mengajar guru (peneliti) mengalami peningkatan dari siklus I ke siklus II hingga Siklus III.

\section{Hasil Belajar pada pelajaran IPA materi Gangguan dan Cara Memelihara Kesehatan Peredaran Darah Manusia}

Hasil penelitian menunjukkan peningkatan hasil belajar pada pelajaran IPA materi Gangguan dan Cara Memelihara Kesehatan Peredaran Darah Manusia. Terlihat pada table berikut:

Tabel 2. Peningkatan Hasil Belajar Siswa

\begin{tabular}{clccc}
\hline \multirow{2}{*}{ NO NAMA } & \multicolumn{3}{c}{ NILAI } \\
\cline { 3 - 5 } & & SIKLUS I & SIKLUS II & SIKLUS III \\
& & & & \\
\hline 1 & ADZRA AURA ZAHRA & 60 & 76 & 80 \\
\hline 2 & ALFIRA EKA SEPTI W & 67 & 77 & 80 \\
\hline 3 & ARISTA DWI LESTARI & 93 & 100 & 100 \\
\hline 4 & ARJUNNA JATA FIRMANSYAH & 63 & 75 & 80 \\
\hline 5 & ARKA DIAN PRATAMA & 76 & 76 & 80 \\
\hline 6 & ARYA BIMANTORO & 90 & 92 & 100 \\
\hline 7 & AZAHRA AYU MAHARANI & 90 & 95 & 96 \\
\hline 8 & BERLIANANTYA R MOZZA & 67 & 75 & 80 \\
\hline 9 & CINTA HARLYNA & 70 & 80 & 82 \\
\hline 10 & DAVIN VERNANDO & 80 & 85 & 87 \\
\hline 11 & DWI LARAS NUR SAPUTRI & & & \\
\hline
\end{tabular}




\begin{tabular}{llccc}
\hline 12 & EVI RISTANTI RAHMANI & 87 & 88 & 90 \\
\hline 13 & FADILLAH TIMIDAR BUMI KINASIH & 83 & 85 & 88 \\
\hline 14 & FAREL GHIBRAN HARYONO & 90 & 95 & 98 \\
\hline 15 & FARIZ OKTAVIAN REHANDHANI & 97 & 100 & 100 \\
\hline 16 & FATHAN AHNAF PRATAMA & 80 & 85 & 90 \\
\hline 17 & GENDHING SEKAR DEWANTI & 76 & 78 & 80 \\
\hline 18 & GENDIS RADHWA MAHESWARI & 63 & 76 & 81 \\
\hline 19 & HABIBUN NAJWAN & 60 & 76 & 85 \\
\hline 20 & KANZA AURA TITANIA & 78 & 79 & 80 \\
\hline Jumlah & $\mathbf{1 5 3 0}$ & $\mathbf{1 6 6 8}$ & $\mathbf{1 7 3 6}$ \\
\hline Rata-rata & $\mathbf{7 6 , 5 0}$ & $\mathbf{8 3 , 4 0}$ & $\mathbf{8 6 , 8 0}$ \\
\hline Nilai Tertinggi & $\mathbf{9 7}$ & $\mathbf{1 0 0}$ & $\mathbf{1 0 0}$ \\
\hline Nilai Terendah & $\mathbf{6 0}$ & $\mathbf{7 5}$ & $\mathbf{8 0}$ \\
\hline Tuntas & $\mathbf{1 2}$ & $\mathbf{2 0}$ & $\mathbf{2 0}$ \\
(Persentase) & $\mathbf{( 6 0 \% )}$ & $\mathbf{( 1 0 0 \% )}$ & $\mathbf{( 1 0 0} \%)$ \\
\hline Belum Tuntas & $\mathbf{8}$ & - & - \\
(Persentase) & $\mathbf{( 4 0 \% )}$ & & \\
\hline
\end{tabular}

Pada siklus I penggunaan video pembelajaran belum dilaksanakan secara optimal oleh guru. Pada akhir pembelajaran, setelah guru mengadakan tes formatif ternyata nilai yang diperoleh siswa belum sesuai dari yang diharapkan. Peneliti bersama teman sejawat mencari permasalahan tersebut. Kesimpulannya siswa belum dapat memahami serta menguasai materi Gangguan Dan Cara Memelihara Kesehatan Organ Peredaran Darah Manusia pelajaran IPA. Hal ini dapat dilihat dari hasil nilai formatif. Dari sejumlah 20 siswa pada prasiklus yang memperoleh nilai sesuai standar KKM 75,00 ketuntasan belajar 8 siswa atau $40 \%$..Melihat hal tersebut maka perlu adanya perbaikan pembelajaran siklus I.Untuk memperbaiki dan meningkatkan prestasi belajar siswa, maka pada siklus I guru berupaya meningkatkan hasil belajar materi Gangguan Dan Cara Memelihara Kesehatan Organ Peredaran Darah Manusia pelajaran IPA dengan menggunakan media video pembelajaran. Selain itu guru berupaya maksimal untuk menciptakan suasana belajar di kelas lebih aktif, kreatif, dan menyenangkan untuk membuat siswa lebih aktif dalam mengikuti proses pembelajaran. Dari hasil pengamatan oleh teman sejawat pada perbaikan siklus I dari 12 siswa banyak yang mengalami peningkatan nilai tes formatifnya. Namun demikian masih ada 8 siswa yang belum tuntas. Pada siklus I sudah berhasil meningkatkan pemahaman siswa namun belum sepenuhnya tercapai ketuntasan belajar. Hasil evaluasi pada akhir siklus I, rata-rata 76,50 sudah meningkat dari rata-rata sebelum perbaikan pembelajaran. Demikian pula prosentase ketuntasan belajar meningkat dari jumlah siswa yang tuntas $40 \% \%$ menjadi $60 \%$. Jadi prosentase kenaikan dari Pra Siklus ke Siklus I adalah $20 \%$. Menindaklanjuti dari hal tersebut maka peneliti perlu mengadakan perbaikan pembelajaran siklus II untuk meningkatkan pemahaman siswa pada materi Gangguan Dan Cara Memelihara Kesehatan Organ Peredaran Darah Manusia pelajaran IPA dengan mengoptimalkan penggunaan media video pembelajaran.

Pada siklus II penggunaan media video pembelajaran dilaksanakan secara optimal oleh guru. Pada akhir pembelajaran, setelah peneliti mengadakan tes formatif ternyata nilai yang diperoleh siswa sesuai yang diharapkan. Hal ini dapat dilihat dari hasil nilai formatif. Dari sejumlah 20 siswa yang mencapai ketuntasan belajar sejumlah 20 atau $100 \%$ dengan rata-rata kelas 83,40 . Proses pembelajaran siklus II sudah menunjukkan adanya peningkatan. Hal ini dapat dilihat dari meningkatnya nilai rata-rata tes formatif dari siklus I yaitu 76,50 menjadi 83,40 . Peningkatan hasil rata-rata 
ini dikarenakan guru dalam proses pembelajaran lebih optimal dengan menggunakan media video pembelajaran. Siswa yang telah mencapai ketuntasan belajar pada siklus II berjumlah 20 orang atau $100 \%$ dengan rata-rata 83,40. Kenaikan prosentase ketuntasan belajar dari Siklus I ke Siklus II mencapai $40 \%$, yaitu dari 60\% menjadi $100 \%$. Hasil pengamatan teman sejawat, terlihat bahwa setelah menjelaskan materi Gangguan Dan Cara Memelihara Kesehatan Organ Peredaran Darah Manusia pelajaran IPA melalui penggunaan media video pembelajaran, kemampuan pemahaman siswa pada materi gangguan kesehatan organ peredaran darah manusia dan upaya pencegahannya pelajaran IPA meningkat, dibuktikan dengan hasil perolehan nilai yang dicapai oleh siswa dalam tes siklus II meningkat, akan tetapi ratarata kelas belum mencapai nilai 85,00 , sehingga dilakukan perbaikan pembelajaran siklus III.

Pada siklus III penggunaan media video pembelajaran dilaksanakan lebih optimal oleh guru. Pada akhir pembelajaran, setelah peneliti mengadakan tes formatif ternyata nilai yang diperoleh siswa sesuai yang diharapkan. Hal ini dapat dilihat dari hasil nilai formatif. Dari sejumlah 20 siswa yang mencapai ketuntasan belajar sejumlah 20 atau $100 \%$ dengan rata-rata kelas 86,80 . Proses pembelajaran siklus III sudah menunjukkan adanya peningkatan. Hal ini dapat dilihat dari meningkatnya nilai rata-rata tes formatif dari siklus II yaitu 83,40 menjadi 86,80 . Peningkatan hasil ratarata ini dikarenakan guru dalam proses pembelajaran lebih optimal dengan menggunakan media video pembelajaran. Berdasarkan penjelasan yang sudah yang sudah diuraikan diatas, maka peneliti tidak melanjutkan perbaikan, karena kemampuan pemahaman siswa pada materi Gangguan Dan Cara Memelihara Kesehatan Organ Peredaran Darah Manusia pelajaran IPA yang dicapai siklus III telah mengalami peningkatan yang signifikan. Siswa yang telah mencapai ketuntasan belajar pada siklus II berjumlah 20 orang atau $100 \%$ dengan rata-rata 86,80 . Kenaikan hasil rata-rata kelas dari Siklus II ke Siklus III mencapai 3,4. Hasil pengamatan teman sejawat, terlihat bahwa setelah menjelaskan materi Gangguan Dan Cara Memelihara Kesehatan Organ Peredaran Darah Manusia pelajaran IPA melalui penggunaan media video pembelajaran, kemampuan pemahaman siswa pada materi gangguan kesehatan organ peredaran darah manusia dan upaya pencegahannya pelajaran IPA meningkat, dibuktikan dengan hasil perolehan nilai yang dicapai oleh siswa dalam tes siklus III meningkat, yaitu menjadi 86,80 .

\section{SIMPULAN}

Uraian hasil Penelitian pada Penelitian Tindakan Kelas dan pembahasan pada bab sebelumnya yang berjudul Penggunaan Media Video Pembelajaran Untuk Meningkatkan Pemahaman IPA Materi Gangguan Dan Cara Memelihara Kesehatan Organ Peredaran Darah Manusia melalui Penggunaan Media Video Pembelajaran pada Siswa Kelas V Semester Ganjil SD Negeri 3 Temanggung II Tahun Pelajaran 2020/2021. Dapat diambil kesimpulan sebagai berikut:

(1) Dalam penelitian tindakan kelas ini peneliti meneliti tentang pemahaman siswa pada pelajaran IPA.

(2) Hasil belajar siswa sebelum menggunakan Media video Pembelajaran pada pelajaran IPA materi Gangguan dan cara memelihara kesehatan organ peredaran darah manusia memiliki hasil belajar dengan ketuntasan $40 \%$. Dalam hal ini hasil belajar peserta didik masih di bawah indikator keberhasilan dan ingin dilakukan perubahan.

(3) Berdasarkan hasil penelitian pada siklus I, siklus II, dan siklus III setelah diterapkannya Model Pembelajaran dengan menggunakan Media video Pembelajaran dapat meningkatkan pemahaman peserta didik pada pelajaran IPA materi Gangguan dan cara memelihara kesehatan pada organ peredaran darah manusia. Hal ini dapat 
dibuktikan dengan hasil belajar peserta didik yang meningkat setelah diterapkannya Model Pembelajaran menggunakan Media video Pembelajaran.

Pada tahap Pra Siklus ketuntasan kelas hanya 40\%. Pada Siklus I rata-rata 76,50 dengan ketuntasan $60 \%$. Pada Siklus II rata-rata 83,40 dengan ketuntasan mencapai 100\%. Dan pada siklus III Tuntas 100\% dengan kenaikan rata-rata menjadi 86,80.

\section{DAFTAR PUSTAKA}

Arsyad, A. (2014). Media Pembelajaran. Jakarta: Raja Grafindo Persada.

Hamalik, Oemar. (1989). Media Pendidikan. Bandung : Citra Aditya

Riyana, C. (2008). Peranan teknologi dalam pembelajaran. Jakarta : Universitas Indonesia

Sadiman, Arief S., dkk .(2008). Media Pendidikan: Pengertian, Pengembangan, dan Pemanfaatannya. Jakarta: PT Raja Grafindo Persada.

Sapriati, Amelia dkk. 2014. Materi pokok Pembelajaran IPA di SD. Tangerang Selatan : Universitas Terbuka

Slameto. (2003). Belajar dan Faktor-faktor yang mempengaruhinya. Jakarta: Rineka Cipta.

Sudjana, Nana. (2009). Penilain Hasil Proses Belajar Mengajar. Bandung: Remaj Rosdakarya

Wardani, IGAK. (2014). Materi Pokok Penelitian Tindakan Kelas. Tangerang Selatan : Universitas Terbuka 